\section{Physiotherapy practices in primary health care}

\author{
Práticas fisioterapêuticas para \\ a produção do cuidado na \\ atenção primária à saúde
}

\author{
Cíntia Raquel Bim (10 ${ }^{1 *}$ \\ Brígida Gimenez de Carvalho (D) ${ }^{2}$ \\ Celita Salmaso Trelha (iD ${ }^{2}$ \\ Kátia Suely Queiroz Silva Ribeiro (i) ${ }^{3}$ \\ Rossana Staevie Baduy (1) 2,4 \\ Alberto Durán González (10 ${ }^{2}$ \\ Universidade Estadual do Centro-Oeste (UNICENTRO), \\ Guarapuava, PR, Brazil \\ 2 Universidade Estadual de Londrina (UEL), Londrina, PR, Brazil \\ ${ }^{3}$ Universidade Federal da Paraíba (UFPB), João Pessoa, PB, Brazil \\ ${ }^{4}$ Universidade Federal do Rio de Janeiro (UFRJ), Rio de Janeiro, \\ RJ, Brazil
}

Date of first submission: July 4, 2020

Last received: December 23, 2020

Accepted: March 16, 2021

Associate editor: Angelica Vieira Cavalcanti de Sousa

*Correspondence: crbim@unicentro.br

\begin{abstract}
Introduction: Physiotherapy was included in primary health care $(\mathrm{PHC})$ in order to expand access and provide comprehensive care to the population. Objective: To understand the routine and tools used by physiotherapists in primary health care and analyze the determining factors in providing care in a municipality where every basic health unit (BHU) has a physiotherapist. Methods: This is a qualitative study of nineteen physiotherapists conducted in a city of Southern Brazil, using a semistructured interview and a methodological framework for discourse analysis. Results: The main tools routinely used in the physiotherapy service are individual appointments, home visits and group work. Physiotherapy practices are influenced by public health, municipal management and $\mathrm{BHU}$ policies, physiotherapy profile in addition to the characteristics of the coverage area and the population being treated. Introducing health promotion measures and implementing relational technologies are the main challenges for physiotherapists, and many of these professionals already recognize their importance in promoting comprehensive care. Conclusion: Physiotherapy practices and the tools used are in line with the Primary Care Family Health Support Center (NASF-AB) model of action recommended by public policies and have been effective for many health conditions. Knowing the routine of PHC physiotherapy services may help professional training and service management, with a view to producing physiotherapy care aimed at the principle of comprehensiveness and consolidating the role of physiotherapists at this level of care.
\end{abstract}

Keywords: Comprehensive health care. Physiotherapy. Primary health care. Professional practice. Public health policies. 


\section{Resumo}

Introdução: A fisioterapia foi inserida no contexto da atenção primária à saúde (APS) como forma de ampliar o acesso da população e proporcionar a integralidade do atendimento à saúde das pessoas. Objetivo: Compreender a rotina e as ferramentas utilizadas por fisioterapeutas na atenção primária à saúde e analisar seus determinantes para a produção do cuidado em um município que possui fisioterapeutas em todas as unidades básicas de saúde. Métodos: Realizou-se pesquisa qualitativa em uma cidade do sul do Brasil, com 19 fisioterapeutas, através de entrevista semiestruturada e referencial metodológico de análise do discurso. Resultados: As principais ferramentas utilizadas na rotina do serviço de fisioterapia no contexto estudado são: atendimentos individuais, visitas domiciliares e trabalho em grupos. As práticas fisioterapêuticas são influenciadas por políticas públicas de saúde, gestão municipal e da unidade de serviço, perfil dos fisioterapeutas e características do território e da população assistida. Realizar ações de promoção em saúde e implementar tecnologias relacionais são desafios para o fisioterapeuta, mas muitos profissionais já reconhecem essas práticas para promover o cuidado integral. Conclusão: As ações fisioterapêuticas realizadas e ferramentas utilizadas estão em consonância com o modelo de atuação do Núcleo Ampliado de Saúde da Família e Atenção Básica preconizado pelas políticas públicas e têm sido resolutivas para muitas condições de saúde. Conhecer a rotina de serviços de fisioterapia na APS pode subsidiar discussões no âmbito da formação profissional e de gestão de serviços, com vistas à produção do cuidado fisioterapêutico pautado no princípio da integralidade e a consolidar a atuação do fisioterapeuta neste nível de atenção.

Palavras-chave: Assistência integral à saúde. Fisioterapia. Atenção primária à saúde. Prática profissional. Políticas públicas de saúde.

\section{Introduction}

Primary health care $(\mathrm{PHC})$, the preferred entry level of a health system, is characterized by the continuity and comprehensiveness of health measures. It forms the basis and determines the work of other care levels, guided by the main health problems of the community, which vary from country to country. ${ }^{1}$ The World Health Organization (WHO) recommends that $\mathrm{PHC}$ involves social justice, equal support, community participation, comprehensive care, intersectoral collaboration, interprofessional teams and health promotion. ${ }^{2}$

In Brazil, the National Health System (SUS) is public and universal and its Family Health Strategy (FHS), controlled by the Ministry of Health, is a pillar of the health care model and the entry point to $\mathrm{PHC}$, also known as basic health care. ${ }^{3}$ With a view to broadening the scope of PHC in Brazil, the Family Health Support Center (NASF) was created in 2008 and was the first public health policy that regulated physiotherapy in the PHC context. It was reformulated in 2017 and became known as the Expanded Center for Family Health and Basic Care (NASF-AB). ${ }^{4}$

The NASF was implemented to broaden the scope of PHC and meet the goal of comprehensive health care. It aims to develop skills related to family health, and is committed to improving intersectoral and interdisciplinary performance, curing and promoting, preventing and rehabilitating health, in addition to humanizing care, continuing education, promoting comprehensiveness and the territorial organization of health services. ${ }^{4}$ Ministry of Health documents contain guidelines and technological tools for the organization and development of NASF working processes: matrix support (main technological tool), expanded clinical care, singular therapeutic project (PTS), health project in the territory (PST), group-based work, genogram, ecomap, shared home care, shared individual care and specific individual care. ${ }^{4,5}$

The use of tools contributes to the shared work of the FHS teams, in conjunction with community and healthcare networks. ${ }^{6}$ It is indispensable that healthcare personnel have instruments that allow them to foster professional-patient relationships based on listening and confidence, and better understand the singularity and cultural universe of patients, which enriches and expands the clinical reasoning of professionals. ${ }^{7}$

With their training based on the biomedical cure model, PHC physiotherapists seek new meanings in their professional practices, considering patients in their biopsychosocial context, in order to promote comprehensive care with a focus on human functionality. ${ }^{8}$ Several possibilities for practices and strategies to reformulate physiotherapy have been implemented in PHC not only in Brazil, but several other countries. ${ }^{9-12}$

The predominance and multicausality of chronic health conditions and their repercussions on the 
func-tional capacity of individuals reinforce the importance of including physiotherapists in $\mathrm{PHC}$ policies. ${ }^{2}$ With the reorganization of PHC to overcome fragmented health care in Brazil, professionals had to rethink their work processes. Physiotherapists are faced with the challenge of a compiling a theoretical and epistemological corpus on sharing specific knowledge of the profession for health policies, in order to contribute to the social transformations needed to promote adequate health conditions and ensure comprehensive care. ${ }^{13,14}$ Another challenge is to make municipal managers aware of the importance of including this professional on the PHC team, by identifying physiotherapy care needs. ${ }^{15}$ Thus, the present study started with the following question: what are the practices performed and tools used by PHC physiotherapists? The aim was to identify physiotherapy practices and analyze their determining factors for providing comprehensive care to SUS patients in a large city.

\section{Methods}

\section{Design}

This is a qualitative study using discourse analysis. Qualitative research incorporates meaning and intentionality as inherent to actions, relations and social structures, and is the most appropriate for acquiring knowledge and assessing health problems and policies. ${ }^{16}$ The discourse analysis adopted was proposed by Martins and Bicudo, ${ }^{17}$ and consists of two moments: individual or ideographic analysis, where the units of meaning, which are words or sentences that have meaning from the standpoint of the central issue, are identified; and overall or nomothetic analysis, where individual cases are understood and combined to create categories that organize the phenomenon under study.

\section{Characterization of the municipality and health care} network

Londrina, a large Brazilian city in northern Paraná state, is the fourth most populous in Southern Brazil.

In 2017, Londrina had a population of 563,943 inhabitants, with 84 FHS and 10 NASF teams distributed in 54 basic health units (BHUs). A total of 42 physiotherapists worked in the municipal government,
33 in BHUs, four in rural BHUs to support the FHS team and 29 with NASF-AB teams. In large BHUs, physiotherapists work five days a week, in mediumsize facilities, three days a week, and in small units two days a week, with a weekly workload of 30 hours per professional.

\section{Participants}

A total of nineteen PHC physiotherapists working in the BHUs of Londrina, Paraná state, Brazil, were selected by convenience. Inclusion criteria were age, time since graduation, professional qualification, time working in basic care and number of days working at the BHU.

Initially, the 33 physiotherapists working in BHUs completed a characterization questionnaire. After their profile was identified, the participants were selected for interviews, and the following aspects considered for sample heterogeneity: time since graduation, academic degree, time working in $\mathrm{PHC}$, type of $\mathrm{BHU}$ (urban or rural), and affiliation with the $\mathrm{BHU}$. A total of 19 professionals were interviewed.

\section{Data collection}

The interviews were scheduled and conducted the subjects' workplace between August and October 2017. A script was used for the semistructured interviews, facilitating the approach and ensuring that the assumptions would be covered during the conversation. The script included questions about including physiotherapists in PHC; work routine: practices performed and tools used in the $\mathrm{BHU}$ to provide care; the role of physiotherapy in PHC and knowledge of the pertinent legislation; health promotion: concepts and practices, facilities and difficulties in executing tasks. The interviews were recorded and transcribed by the researchers.

\section{Data analysis}

A total of nineteen interviews were conducted, varying between 25 and 82 minutes (average of 41 minutes), totaling approximately 14 hours of audio. In the transcription, an attempt was made to preserve all the characteristics possible. During the transcription process, codes were assigned to the discourses to guarantee anonymity, using the letter $F$ and a number, in the order of the interviews. 


\section{Ethical aspects}

This study complied with the ethical aspects and regulatory guidelines for research involving human beings, and was conducted only after the objectives were explained and the subjects provided written informed consent. It was approved by the Research Ethics Committee of the State University of Londrina, Paraná state, Brazil, under protocol CAAE 67961917.0.0000.5231 of 2017.

\section{Results}

\section{Physiotherapy practices in PHC}

The standard work routine of physiotherapists mainly involves specific individual treatment, group-based work and home visits, the routine stipulates certain days for home visits, group physiotherapy days that are mine, and scheduled individual sessions (F11). Other activities sited as part of the routine varied significantly in terms of the professional profile, relationship with health unit management, the FHS and NASF teams, and the characteristics of the population treated.

Specific individual sessions were the most commonly performed by the physiotherapists of the municipality studied, due to spontaneous demand, and this approach generally included assessments, in order to establish objectives and devise a treatment plan. Self-care and coresponsibility in treatment are encouraged (F11). After the consultation, the patient could have a return visit with the physiotherapists, be referred for BHU functional kinetic group activities or to an affiliated medium complexity clinic.

Due to the high demand for individual physiotherapy treatment in $\mathrm{PHC}$, practices have focused more on care and rehabilitation than health promotion and prevention: Everywhere I do more care-based work (F2); I think around $80 \%$ is treatment... (F9); I think that about half (F13); Ah... it's about $70 \%$ rehabilitation and $30 \%$ promotion (F19). However, some professionals used the consultation for health education purposes: Since most of the people I see are for individual assessment, guidelines are given individually (F10).

Group-based work is another physiotherapy practice in $\mathrm{PHC}$, and the most common are pain and stretching groups (F16), in order to meet this frequent demand in
BHUs. The other groups varied from one unit to another, some of which were interprofessional, such as smokers, obese individuals, those with shoulder and back problems, pregnant women, strengthening exercises, isostretching, dance therapy and auriculotherapy. Some groups are weekly and others are offered in modules, such as the smokers' group (F18). Most of the group sessions took place in churches near the BHUs, through intersectoral partnerships. Group patients presented with fewer acute pain crises: The group experience has been very good. People don't want to return to the clinics, and don't want to leave the group (F12).

Most home visits involved acute and/or bedridden cases, the aim is to provide advice on the new condition of the patient being treated (F12), and the physiotherapist is usually accompanied by a community health agent (F15). When there is a need for secondary care, patients are referred to a partner clinic. Some patients and caregivers believed the physiotherapy would take place at home, but this is not the current health policy, which reflects people's lack of understanding regarding the role of physiotherapists in PHC (F12).

At home, the visits were not always shared by the team. According to the interviewed subjects, home visits are effective when the family or caregiver participates, but this does not always happen (F15).

Professional practices reported by some but not all physiotherapists included monthly continuing education meetings, creation of a coverage area map, patient referral to the orthosis and prosthesis service and aquatic therapy.

Although the use of technological tools from the NASF is part of physiotherapy practices, where matrix support (a form of multiteaming) and the singular therapeutic project were the most commented, some tools recommended for PHC were still not part of the routine in the municipality studied. Now, matrix support is only used in health education. For example, the last time I spoke about transfers and fall prevention, we worked with the team, the community health agents, and the assistants on health education. Case studies and such are not being discussed (F9).

Physiotherapists report difficulties in measuring and recording the efficacy of their actions, in terms of assessment and follow-up of their patients' evolution, which compromises the recognition and scientific construction of physiotherapy practices in PHC. In daily practice, you don't prioritize, so we can't provide 
indicators for anything (F19). Another difficulty was the use of relational or light technologies, such as creating a bond, humanization and the work management process, an issue still little discussed or applied in Brazilian physiotherapy services.

Access to medium complexity care and the quality of the services provided by outsourced clinics were also described as a shortcoming of the network, which affects physiotherapy practice. We have a serious problem with SUS-authorized clinics. Lack of quality, it's very sad to say. The SUS pays poorly, the clinics pretend to treat and the patients pretend they're being treated (F12). At the clinics, patients are often only treated with electrotherapy, and according to the physiotherapists of the municipality doing 20 minutes of electrotherapy and being sent home is not physiotherapy (F15).

\section{Health promotion practices in $\mathrm{PHC}$}

In relation to health promotion in the work routine, the answers were varied. Reports show that some professionals do not promote health, others attempt to do so and still others feel that they manage to promote health satisfactorily despite the limitations. Some discourses regarding health promotion include: Very little, very little, ... because the team doesn't value it (F2); Ah, I think quite a bit... Everybody works together, I think we're heading in the right direction with health promotion (F3); I try... we work hard all the time to prevent the risks from increasing in these groups (F13).

A significant boost to health promotion measures were commemorative dates, such as Pink October, which promotes breast cancer prevention and Blue November, which encourages men's health care. With these measures, you can offer advice, try to disseminate information, even if it's just a single patient that you're treating for something else (F11).

Most of the physiotherapists that promote health do so in groups, by virtue of the patient-therapist bond created. Some physiotherapists consider health education as promotion and use these group spaces for health education, on the commemorative dates at the BHU (F9).

Professional profile was a factor for health promotion measures, since some were motivated to propose new approaches in their routine: I don't think every BHU is as open to new ideas as ours... we propose an activity and management tells us to do it and then see if it worked (F3). Unique practices reported included art therapy (F3), analyzing the dreams of adolescents (F13), dance therapy (F18) and auriculotherapy (F2, F10).

The interest of the population also influenced promotion practices: We try. But we face a lot of resistance from patients (F14). Some patients are uninterested because they do not consider health promotion a valid strategy, while others recognize the importance of these actions: with the consolidation of the NASF, people are joining more groups (F19).

The way in which the municipal service is organized is reflected in the practices performed. Some physiotherapists feel there is no opportunity for health promotion: actually, we are there to assess the patient, but ideally we should be promoting health (F14). One of those interviewed considered that the municipality already had the professionals, but that they needed to restructure the NASF, because what the NASF is doing today is not the NASF, since $70 \%$ rehabilitation and 30\% promotion is not its true purpose; so physiotherapists have a more clinical than health promoting role (F19).

The physiotherapists of the municipality understand that some organizational aspects of the service need to be revised in order to enhance the care provided to the patients. This means expanding activities to include health promotion measures: Improve our availability to perform more NASF practices... I think there's lack of organization in planning these activities (F17).

\section{Discussion}

The work of physiotherapists in PHC, within the NASF$A B$ policy, has been increasingly debated in recent years, but there are still gaps in its understanding. The NASF$A B$ guidelines recommend that team services should always focus on their coverage area, based exclusively on referrals from family health teams; and that the service be structured to prioritize shared interprofessional treatment, with an exchange of knowledge, training and mutual responsibilities. ${ }^{4}$

Starting from the new National Basic Care Policy (PNAB) published in 2017, NASF-AB teams began assisting traditional $\mathrm{BHU}$ teams; ${ }^{18}$ however, this occurred at the time of data collection, precluding considering it in the discussion. Nevertheless, it is important to underscore that the teams were put at risk because the changes 
to their funding model compromised their expansion and very existence. The NASF-AB can contribute to the production of comprehensive care in the SUS and, in this respect, provides a number of possibilities, but others can also be created at team meetings. ${ }^{5}$

Assessment during individual treatment is one of the activities performed by physiotherapists, and they must be able to conduct clinical screening at the first PHC contact. ${ }^{2}$ Given that musculoskeletal disorders are frequent in the general population and can be considered one of the major public health problems worldwide, ${ }^{19}$ the demand for musculoskeletal assessments is frequent in PHC. By contrast, in order to improve the health of the population, prevention, promotion, education and treatment must be prioritized, incorporating the broad concept of health and autonomy. However, the time spent on these measures is incipient when compared to that dedicated to spontaneous demand, generating an excessive number of individual consultations. ${ }^{20}$ In the present study, the spontaneous demand for individual treatment predominates in BHUs, occupying more than half of physiotherapists' time. Thus, it can be considered that health professionals are in a vulnerable situation, due to the large demand for individual treatment, which prevents NASF professionals from expanding their care options. ${ }^{21}$ In this respect, it would be necessary to organize the municipal service studied to allow physiotherapists to broaden their services.

Group work, an important resource in $\mathrm{PHC}$ care, can be carried out in different modalities. Irrespective of its organization, shared care goes beyond just meeting biological needs and addresses the educational, psychological and social aspects of a group of people. ${ }^{22}$ When groups are based on bonds, listening and support, they are a collective space for reflection, learning and decision making, creating health promotion opportunities, strengthening participants and preventing disease. ${ }^{6}$ Accordinbg to Fernandes et al., ${ }^{23}$ that patients have a positive perception about the group activities offered by the NASF, underscoring satisfactory therapeutic results and the creation of affective bonds, thereby strengthening interpersonal relations, wellbeing and improving quality of life.

Home visits involve physiotherapists going to the patient's home to provide care, learning or to investigate. ${ }^{24}$ This working tool is indispensable for PHC physiotherapists as a means of promoting access and providing referrals and guidance for each case. $8,10,24$
Physiotherapists that act beyond the standard established in the municipality are considered workers with creative potential who use new practices not included in the guidelines and protocols. ${ }^{25}$ Given that the proposal is unique to the municipality and that each BHU has its own management, analysis of the discourses regarding physiotherapy practices revealed the potential of each worker within their coverage area.

The technological tools of the NASF are innovative and essential in horizontal relationships between professionals. These new arrangements and working tools require new understanding of health-related work and a training process that allows professionals to acquire the skills to jointly face the challenges encountered. ${ }^{14}$

Matrix support, the central element of the NASF proposal, contains two support dimensions: care support (clinical measures applied directly to patients) and technical-pedagogical action, which provides educational support for the team to share knowledge in the search for a solution to the population's needs. ${ }^{5}$ The technical-pedagogical dimension is the most fragile in terms of the role of physiotherapy in the NASF, demonstrating the need to develop continuing education in health services in order to implement the actions recommended for physiotherapists, where matrix support involves interprofessional collaboration and knowledge sharing, working in networks, acting in an established coverage area, joint deliberation and comanagement. ${ }^{10,14}$ Whether due to internal or external team issues, the technological tools proposed by the NASF guidelines, such as matrix support, expanded clinical care and the PTS, are still underused and need to be part of the daily routine of physiotherapists in order to achieve effective care. ${ }^{26}$

The PTS, for example, is not consistently implemented by the NASF in Londrina and other Brazilian municipalities, due to the amount of time needed and the difficulty in organizing the schedule of the different personnel involved. ${ }^{6,26}$ In the municipality under study, this tool was used by some of the professionals. The use of a genogram and ecomap, which allows visualizing the relation between patients and their family, the environment and the community, was not reported by the individuals interviewed.

Tools for use in the NASF are little represented, perhaps due to the resistance of professionals in adding to their work routine, in addition to the lack of knowledge and training profile of some professionals. ${ }^{6}$ 
Physiotherapists need to consider the social determinants in the health-disease process of patients, where a familybased and social approach represents a new healthcare perspective ${ }^{27}$ aided by technological tools. ${ }^{25}$

Physiotherapists should also emphasize relationshiporiented light technologies, which foster humanization and the formation of the professional/patient bond, thereby making their work as health promoters more effective. ${ }^{13}$ The discourses on the use of these technologies were incipient in this study. The change in the care model is achieved by reorganizing the work process of all the health professionals, where practices are determined by the use of light technologies able to produce care. ${ }^{7,28}$

The shortcomings in the recording and execution of systematized planning, primarily in monitoring and assessment practices, compromises its organization and effectiveness. ${ }^{29}$ The physiotherapists studied were required to keep a mandatory record of services provided, but generally registered these in the information systems as treatment provided, without a detailed description of the actions or assessments systematized by specific instruments. In addition, health problems need to be investigated in the community in both their biological and social conditioning factors, and it is important to continuously monitor health status to assess patients' evolution. ${ }^{2}$ A study conducted to analyze the work of the NASF in Brazil in 2013 and 2014, found that in $45.5 \%$ of the teams, monitoring and analysis of indicators, in addition to initial training and continuing education, remain poorly exploited in $\mathrm{PHC} .{ }^{30}$

A number of municipal health professionals do not value or emphasize health promotion measures in their daily routine, since they believe that individual treatment should be prioritized. Others feel that professionals should use intersectoral initiatives for health promotion in order to reach people before they fall sick. In the municipality studied, health promotion measures are implemented sporadically in some BHUs, by some professionals.

The National Health Promotion Policy was implemented in 2006 and revised in 2010,31 with specific areas for professional practice: dissemination and implementation of the policy, a healthy diet, physical activity, prevention and control of smoking, reduction of mortality and morbidity caused by excessive alcohol consumption, other drugs, and traffic accidents, violence prevention, encouraging a culture of peace and promoting sustainable development. The physiotherapists' reports show that many actions address the areas proposed by the policy, such as physical activity and preventing and controlling smoking, reinforcing their importance in promoting professional practice.

Health education is a powerful tool used in primary care with a view to enhancing the effectiveness of health services and encouraging patients to assume coresponsibility for their own care. ${ }^{2}$ This practice was the most reported as health promotion in the interviews. Physiotherapists apply it to nearly all their activities, such as individual and group consultations, home visits and school-based actions. Health promotion practices can lead to measures that strengthen subjects and groups by increasing their autonomy and supporting participation and networks. ${ }^{22}$

Professionals that used health promotion measures more frequently were those with up to 10 years of experience, average time in $\mathrm{PHC}$ of 5 to 10 years, and a graduate degree in public health. Added to these factors are personal characteristics such as job satisfaction, proactivity and bonds with the population, which contribute to implementing health promotion. ${ }^{20}$

The way physiotherapy services are structured differs between Brazilian municipalities, considering sociodemographic and organizational contexts and professional profile, but literature findings show that spontaneous demand governs many of the actions. ${ }^{8,13,20}$ Humanization, social participation, operational groups, territorialization, health education measures, acting according to health status, working on an interdisciplinary team, home visits, prevention strategies and health promotion, are described in the literature as part of a physiotherapist's routine in $\mathrm{PHC} .^{8}$ However, there are contradictions between NASF-based health care and the different care models involved, causing tension between stakeholders (managers, professionals and patients). One of the strategies to strengthen the NASF$A B$ is to incorporate assessment and monitoring into team routines to ensure that information is understood and used in management strategies to help overcome adversities in the organization and the functioning of PHC practices. ${ }^{27}$

The role of physiotherapists is to improve the functional health of people in a biopsychosocial setting, incorporating technological tools and relational technologies into primary health care with a view to achieving integrality and consolidating their practices. 


\section{Conclusion}

The present study sought to understand physiotherapy practices and the tools used by physiotherapists and analyze their determining factors in a municipality where these professionals are present in all the BHUs. Physiotherapy practices in $\mathrm{PHC}$ in the municipality studied are influenced by public health policies, municipal management, professional profile and characteristics of the coverage area and population cared for.

Knowing the routine of physiotherapy services in $\mathrm{PHC}$ may enrich discussions regarding professional training and service management, in order to consolidate physiotherapy practices at this level of care. Analysis of the physiotherapists' discourses revealed that the practices implemented and tools used are in line with the NASF model recommended by public policies and have been effective for many health conditions. However, some organizational practices should be improved in the municipality studied, with a view to providing comprehensive care.

\section{Authors' contributions}

CRB conducted all stages of the research and ADG guided them. Both were responsible for writing the article. BGC, CST, KSQSR and RSB were responsible for the formal analysis and review of the article.

\section{References}

1. Starfield B. Atenção Primária - Equilíbrio entre necessidades de saúde, serviços e tecnologia. Brasília: UNESCO; 2002. 726 p.

2. Lopes JM. Modelos de atenção primária à saúde e assistência fisioterapêutica. In: Lopes JM, Guedes MBOG, editores. Fisioterapia na Atenção Primária: manual de prática profissional baseado em evidência. Rio de Janeiro: Atheneu; 2019. p. 55-66.

3. Brasil. Política Nacional de Atenção Básica. Departamento de Atenção Básica. Brasília: Ministério da Saúde; 2012. Full text link

4. Brasil. Ministério da Saúde. Secretaria de Atenção à Saúde. Departamento de Atenção Básica. Cadernos de Atenção Básica - Diretrizes do NASF. Brasília: Ministério da Saúde; 2009. 160 p. Full text link
5. Brasil. Cadernos de Atenção Básica - Núcleo de Apoio à Saúde da Família - Volume 1: Ferramentas para a gestão e para o trabalho cotidiano. Brasília: Ministério da Saúde; 2014. 116 p. Full text link

6. Silva ES, Jucá AL, Amado CF, Rocha LP, Vasconcelos TF, Quirino TRL. Processos de trabalho e ferramentas tecnológicas de atuação do NASF. In: Quirino TRL et al. (Orgs.). O NASF e o trabalho na Atenção Básica à saúde: apontamentos práticos e experimentações. Rio de Janeiro: Editora Fiocruz; 2019. p. 55-84.

7. Merhy EE, Feuerwerker LCM. Novo olhar sobre as tecnologias de saúde: uma necessidade contemporânea. In: Mandarino ACS, Gomberg E (Orgs.). Leituras de novas tecnologias e saúde. Salvador: EDUFBA; 2009. p. 29-56.

8. Miranda FAC. Fisioterapia na atenção primária à saúde propostas para a prática. Curitiba: Appris; 2019. 103 p.

9. Bornhöft L, Larsson ME, Nordeman L, Eggertsen R, Thorn J. Health effects of direct triaging to physiotherapists in primary care for patients with musculoskeletal disorders: a pragmatic randomized controlled trial. Ther Adv Musculoskelet Dis. 2019;11:1759720X1982750. DOI

10. Braghini CC, Ferretti F, Ferraz L. The role of physical therapists in the context of family health support centers. Fisioter Mov. 2017;30(4):703-13. DOI

11. Dufour SP, Lucy SD, Brown JB. Understanding physiotherapists' roles in Ontario Primary Health Care teams. Physiother Can. 2014;66(3):234-42. DOI

12. French HP, Galvin R. Musculoskeletal services in primary care in the Republic of Ireland: an insight into the perspective of physiotherapists. Physiotheraphy. 2017;103(2):214-21. DOI

13. Souza MC, Bomfim AS, Souza JN, Vilela ABA, Franco TB. Fisioterapia e Núcleo de Apoio à Saúde da Família: um estudo sob a ótica dos gestores, profissionais e usuários de saúde da família. Rev APS. 2014;17(2):189-94. Full text link

14. Bispo Jr JP, Moreira DC. Educação permanente e apoio matricial: formação, vivências e práticas dos profissionais dos Núcleos de Apoio à Saúde da Família e das equipes apoiadas. Cad Saude Publica. 2017;33(9): e00108116. DOI 
15. Ribeiro CD, Flores-Soares MC. Desafios para a inserção do fisioterapeuta na atenção básica: o olhar dos gestores. Rev Salud Publica. 2015;17(3):379-93. DOI

16. Minayo MCS. O desafio do conhecimento: pesquisa qualitativa em saúde. 14 ed. São Paulo: Hucitec; 2014. 407 p.

17. Martins J, Bicudo MAV. A pesquisa qualitativa em psicologia - Fundamentos e recursos básicos. 5 ed. São Paulo: Centauro; 2005. $110 \mathrm{p}$.

18. Brasil. Portaria $n^{\circ} 2.436$ de 21 de setembro de 2017. Aprova a Política Nacional de Atenção Básica, estabelecendo a revisão de diretrizes para a organização da Atenção Básica, no Âmbito do Sistema único de Saúde (SUS). Brasília: Diário Oficial da União; 22 set 2017. Full text link

19. Wendt AS, Chaves AO, Urtado CB, Macedo AR, Reis FJJ, Nogueira LAC. Funcionalidade e incapacidade em pacientes comprometimento musculoesquelético. R Bras $\mathrm{Ci}$ e Mov. 2017;25(4):15-22. Full text link

20. Brito GEG, Mendes ACG, Santos Neto PM. O trabalho na Estratégia Saúde da Família e a persistência das práticas curativistas. Trab Educ Saude. 2018;16(3):975-95. DOI

21. Souza MO, Santos KOB. Physical therapists role in Family Health Support Center. Fisioter Mov. 2017;30(2):237-46. DOI

22. Mendes R, Fernandez JCA, Sacardo DP. Promoção da saúde e participação: abordagens e indagações. Saude Debate. 2016;40(108):190-203. DO|

23. Fernandes ETP, Souza MNL, Rodrigues SM. Práticas de grupo do Núcleo de Apoio à Saúde da Família: perspectiva do usuário. Physis. 2019;29(1): e290115. DOI
24. Medeiros PA, Pivetta HMF, Mayer MS. Contribuições da visita domiciliar na formação em fisioterapia. Trab Educ Saude. 2012;10(3):407-26. DOI

25. Baduy RS, Melchior R, Bertussi DC, Stoicov RR, Martins VL. O trabalho em saúde. In: Andrade SM et al. (Orgs.). Bases da Saúde Coletiva. Londrina: Eduel; 2017. p. 247-96.

26. Nascimento AG, Cordeiro, JC. Núcleo Ampliado de Saúde da Família e Atenção Básica: análise do processo de trabalho. Trab Educ Saude. 2019;17(2):e0019424. DOI

27. Quirino TRL, Marques FMAB, Oliveira VB, Silva ES. O NASF e o trabalho na Atenção Básica à Saúde: apontamentos práticos e experimentações. Rio de Janeiro: Editora Fiocruz; 2019. 157 p.

28. Yamaguchi MAV. Apoio matricial na atenção primária à saúde na perspectiva dos profissionais da Estratégia Saúde da Família [dissertação]. Londrina: Universidade Estadual de Londrina; 2014. 103 p.

29. Silva ICB, Silva LAB, Araújo e Lima RS, Rodrigues JA, Valença AMG, Sampaio J. Processo de trabalho entre a Equipe de Atenção Básica e o Núcleo de Apoio à Saúde da Família. Rev Bras Med Fam Comunidade. 2017;12(39):1-10. DOI

30. Brocardo D, Andrade CLT, Fausto MCR, Lima SML. Núcleo de Apoio à Saúde da Família (NASF): panorama nacional a partir de dados do PMAQ. Saude Debate. 2018;42(n. spe 1):130-44. DOI

31. Brasil. Política Nacional de Promoção da Saúde/Ministério da Saúde, Secretaria de Vigilância em Saúde, Secretaria de Atenção à Saúde. 3 ed. Brasília: Ministério da Saúde; 2010. Full text link 